\title{
Effects of sharp eyespot (Rhizoctonia cerealis) on yield and grain quality of winter wheat
}

\author{
Grzegorz Lemańczyk • Hanna Kwaśna
}

Accepted: 22 August 2012 / Published online: 7 October 2012

(C) The Author(s) 2012. This article is published with open access at Springerlink.com

\begin{abstract}
Sharp eyespot caused by Rhizoctonia cerealis was assessed in four winter wheat crops surveyed at four locations in north-central Poland in 20062009. At the four locations symptoms developed on $41.9-67.7 \%$ of shoots of all plants (average of 4 years) and on $49-73.5 \%$ of shoots of diseased plants (average of 4 years). Slight (category 1) disease was most frequent, occurring on $24.4-41.3 \%$ of shoots (range $14.8-51.3 \%$ ); moderate (category 2 ) disease was less frequent, occurring on 16.9-25.5\% of shoots (range 8.9-32.4\%); severe (category 3 ) disease was least frequent, occurring on 3.2-7.1\% (range 0-22.0\%) of shoots. Sharp eyespot affected wheat growth and yield, and grain quality. Disease, especially in the severe category, was associated with significant decreases in plant and ear dry weights, number of grains per ear, grain dry weight per ear and thousand-grain weight, and with increases in grain protein and wet gluten contents, Hagberg falling number and sedimentation value. There was an association
\end{abstract}

G. Lemańczyk

Department of Phytopathology and Molecular Mycology, University of Technology and Life Sciences,

Kordeckiego 20,

85-225 Bydgoszcz, Poland

H. Kwaśna $(\bowtie)$

Department of Forest Pathology,

Poznań University of Life Sciences,

Wojska Polskiego 71c,

60-625 Poznań, Poland

e-mail: kwasna@up.poznan.pl between occurrence of sharp eyespot in stems and colonization of grain by fungi. Alternaria alternata and E. nigrum were the most common species.

Keywords Grain quality $\cdot$ Rhizoctonia cerealis · Sharp eyespot $\cdot$ Wheat

\section{Introduction}

In 2009 the world production of wheat (Triticum aestivum L.) was 682 million tonnes, making it the second most-produced cereal after maize (Anonymous 2010). In the human diet, wheat is the largest source of vegetable protein and provides also carbohydrates, minerals and vitamins (Anonymous 2006). The wheat grain used in human diet has to be of sufficient quality for consistent technological processing and good quality of bakery and other products. The wheat protein, gluten, determines the suitability of grain for baking.

Fungal infection and presence of diseases on wheat plants may affect quantity and quality of grain (Prange et al. 2005; Siuda et al. 2010).

Sharp eyespot caused by the soil-borne fungus Rhizoctonia cerealis van der Hoeven (teleomorph: Ceratobasidium cereale D. Murray \& L.L. Burpee) is a stembase disease of wheat. The disease is also common among other plants of Poaceae including barley, oats and rye.

Rhizoctonia cerealis is present throughout the temperate wheat growing regions of the world. The fungus 
over-winters as mycelium or sclerotia in plant debris or in the soil. Mycelium from infected plant debris or from germinating sclerotia serves as primary inoculum. The fungus does not form asexual spores and the sexual stage is rare in nature. Infection of plants occurs at the root tissues at any time during the growing season. The symptoms in wheat include dark-bordered lesions on stem bases of young and mature plants. Lesions may coalesce into large patches girdling the stem. Sclerotia may be formed between the lower leaf sheath and stem or within the stem lumen of severely infected shoots. The fungus may cause pre- and post-emergence damping off and shoot death of seedlings (Willis 1984; Wiese 1987; Nyvall 1989; Carling and Sumner 1992). Slight incidence of sharp eyespot tends to have little effect on yield. Severe infection of mature shoots may result in small, shrivelled grain and can induce lodging at the second or third internode and cause premature spike senescence or ripening (white heads). Exceptionally, shoots may be killed as the ear emerges from the sheath (Clarkson and Cook 1983; Cromey et al. 2002). The disease is favoured by neutral to slightly acid, dry and sandy soils (Pitt 1964). Cool autumn or spring may result in earlier infection and more severe attacks. Disease incidence tends to be greater in continuously cropped cereals. Practices that help reduce the effects of the disease include crop rotation and late sowing in autumn.

The incidence of sharp eyespot in Europe is increasing (Rossi et al. 1995; Mikolajska and Wachowska 1996; Colbach et al. 1997; Kryuchkova 2000; Tunali et al. 2008; Zhalieva 2008). The increase has been related to:

1. earlier sowing (Colbach et al. 1997);

2. increased use of fungicides, especially those for controlling fusarium root rot (Fusarium spp.) and eyespot (Oculimacula yallundae (Wallwork \& Spooner) Crous \& W. Gams and O. acuformis (Boerema, R. Pieters \& Hamers) Crous \& W. Gams), which decrease microbial antagonism to favour R. cerealis (Prew and McIntosh 1975; van der Hoeven and Bollen 1980);

3. increased geographic distribution of $R$. cerealis and its possible spread to new areas;

4. possible increase in pathogen's aggressiveness after transfer from natural plant communities to agricultural crops (Chakraborty et al. 2000);

5. wider distribution of wheat cultivars susceptible to $R$. cerealis (Cromey et al. 2005);
6. more favourable weather for infection, particularly a combination of a longer, colder pre-winter growing period and wet autumn and spring (Clarkson and Cook 1983).

Formal surveys of sharp eyespot incidence in Poland have not been made. The disease has, however, been observed regularly in recent years (Lemańczyk unpublished), prompting an evaluation of its potential economic effects.

In the present study we determined the incidence and severity of sharp eyespot on wheat crops at four locations in Poland in four growing seasons, 2006-2009, and investigated its effects on grain yield and grain quality.

\section{Materials and methods}

\section{Survey}

Four commercial crops of winter wheat were grown in successive years (harvested in 2006-2009) at each of four sites, Chrzastowo, Minikowo, Mochełek and Sobiejuchy, located 20-70 km apart, in north-central Poland (Kuyavia-Pomerania) (Fig. 1). A different cultivar was grown at each site (Table 1). Each crop was grown as a first wheat, after winter oilseed rape, or as a second wheat (Mochełek in 2007 and 2008). The weather data, type of soil and management procedures for each crop are presented in Table 1.

Incidence and severity of sharp eyespot were determined at growth stages (GS) 13-14, 30-31, 43-45 and 87 , and grain yield and quality were determined at GS 87 (Zadoks et al. 1974) to avoid possible failure in the event of further disease development. The Minikowo site was not sampled in 2008. All plants from four plots $(1 \mathrm{~m} \times 1 \mathrm{~m}$ each $)$, located at similar intervals along a diagonal transect across the field, were harvested by hand. Plants were separated into three groups: those with symptoms of sharp eyespot, those with symptoms of other diseases and those with no symptoms of disease (control).

Sharp eyespot assessment

Sharp eyespot severity was assessed on plants with symptoms of disease, on leaf sheaths and stems of each main shoot and tiller, according to the following 
Fig. 1 Location of surveyed fields in the KuyaviaPomerania Voivodeship

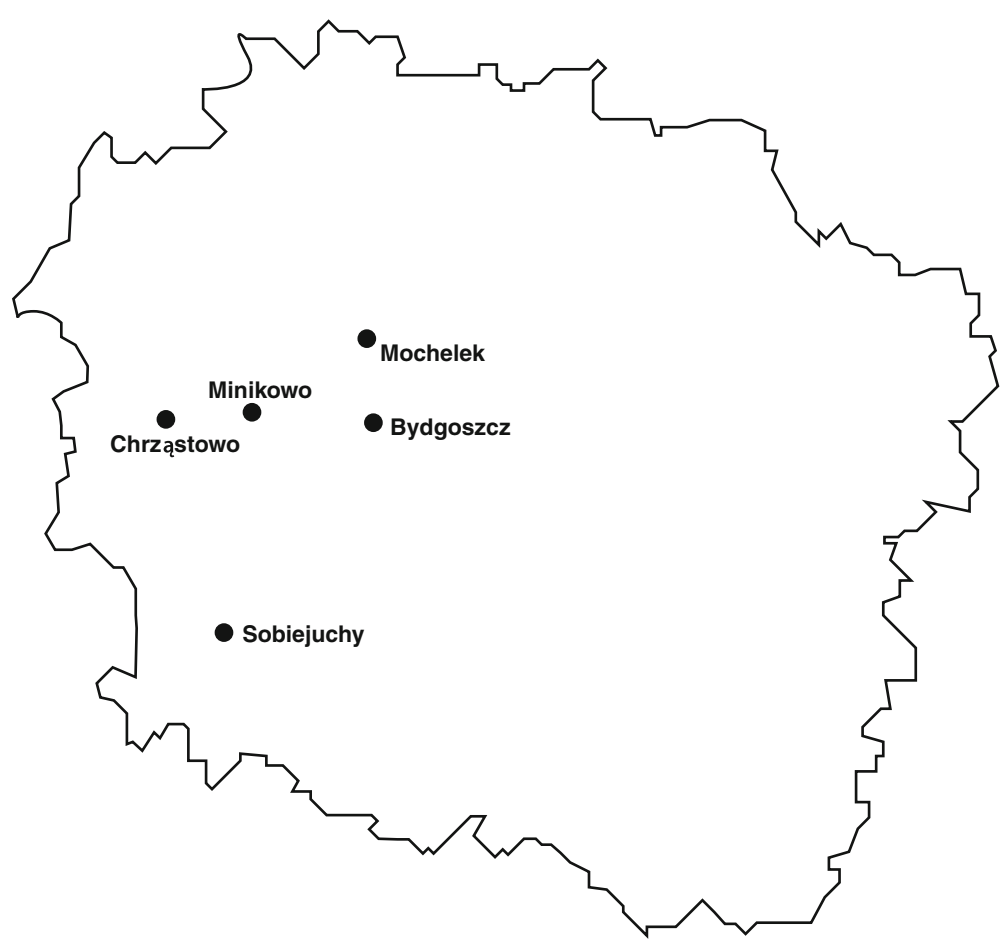

key: 0 - healthy, no symptoms of sharp eyespot; 1 slight disease, one or more lesions on stem girdling in total less than half the stem circumference or on leaf sheath, not penetrating to the stem; 2 -moderate disease, one or more lesions on stem, girdling in total at least half the stem circumference; 3 - severe infection, one or more lesions on stem, girdling in total more than half the stem circumference, stem weakened (Clarkson and Cook 1983).

\section{Detection of Rhizoctonia cerealis}

The presence of $R$. cerealis was confirmed by morphology and molecular analysis. Cultures of fungus grown from infected wheat tissues after their surfacedisinfection in silver nitrate $\left(1 \% \mathrm{AgNO}_{3}\right)$ for $20 \mathrm{~s}$, rinsing in sterile distilled water, sectioning into $1-\mathrm{cm}$ pieces, placing on potato dextrose agar (PDA, Difco + $50 \mathrm{mgl}^{-1}$ streptomycin) and incubation for 14 days at $22{ }^{\circ} \mathrm{C}$, were examined microscopically. Molecular analysis was done after direct extraction of DNA from visibly infected leaf sheaths and stem bases. Primer set Rc2F/R (Nicholson and Parry 1996) was used to establish the presence of $R$. cerealis.
Pathogenicity tests

Mycelium of $R$. cerealis grown on PDA was used to inoculate grain or climate chamber-grown plants. In both tests winter wheat $\mathrm{cv}$. Tonacja was used. The grain was surface-disinfected in mercury (II) chloride (1 \% $\left.\mathrm{HgCl}_{2}\right)$ for $5 \mathrm{~min}$, rinsed in sterile distilled water $6 \times 10 \mathrm{~min}$, placed on sterile wet blotting paper in Petri dishes and incubated at $20-22{ }^{\circ} \mathrm{C}$ for $48 \mathrm{~h}$. Germinated grains were transferred to $10-\mathrm{mm}$ PDA discs with 10day-old $R$. cerealis mycelium on three sheets of sterile, wet (with $16 \mathrm{ml}$ of water) blotting paper per dish $(200 \times 30 \mathrm{~mm})$. Infection was assessed after 7-16 days. Each of four isolates of $R$. cerealis was tested on 80 grains in four Petri dishes.

Plants were inoculated at the beginning of stem elongation (GS 31). Discs of PDA (5 mm) with 14-day-old $R$. cerealis mycelium were applied to the stem base and leaf sheath using Parafilm. Plants were maintained in a climate chamber at $20{ }^{\circ} \mathrm{C}$. Discs were removed after 5 days and plants observed regularly for development of symptoms. 
Table 1 Crop management procedures in first wheat crops grown in 4 years at four sites

\begin{tabular}{|c|c|c|c|c|c|c|c|c|c|c|c|c|}
\hline \multirow{3}{*}{$\frac{\text { Location }}{\text { Geographic coordinates }}$} & & \multicolumn{2}{|c|}{ Chrząstowo } & \multicolumn{3}{|c|}{ Minikowo } & \multicolumn{3}{|c|}{ Mochełek } & \multicolumn{3}{|c|}{ Sobiejuchy } \\
\hline & & \multicolumn{2}{|c|}{$53^{\circ} 09^{\prime} \mathrm{N} 17^{\circ} 35^{\prime} \mathrm{E}$} & \multicolumn{3}{|c|}{$53^{\circ} 29^{\prime} \mathrm{N} 17^{\circ} 56^{\prime} \mathrm{E}$} & \multicolumn{3}{|c|}{$53^{\circ} 13^{\prime} \mathrm{N} 17^{\circ} 51^{\prime} \mathrm{E}$} & \multicolumn{3}{|c|}{$52^{\circ} 54^{\prime} \mathrm{N} 17^{\circ} 43^{\prime} \mathrm{E}$} \\
\hline & \multicolumn{2}{|l|}{$\begin{array}{l}\text { Average } \\
\text { temp. }\left({ }^{\circ} \mathrm{C}\right)\end{array}$} & $\begin{array}{l}\text { Precipitation } \\
\quad(\mathrm{mm})\end{array}$ & \multicolumn{2}{|c|}{$\begin{array}{l}\text { Average } \\
\text { temp. }\left({ }^{\circ} \mathrm{C}\right)\end{array}$} & $\begin{array}{l}\text { Precipitation } \\
\quad(\mathrm{mm})\end{array}$ & \multicolumn{2}{|c|}{$\begin{array}{l}\text { Average } \\
\text { temp. }\left({ }^{\circ} \mathrm{C}\right)\end{array}$} & $\begin{array}{l}\text { Precipitation } \\
\quad(\mathrm{mm})\end{array}$ & \multicolumn{2}{|c|}{$\begin{array}{l}\text { Average } \\
\text { temp. }\left({ }^{\circ} \mathrm{C}\right)\end{array}$} & $\begin{array}{l}\text { Precipitation } \\
\quad(\mathrm{mm})\end{array}$ \\
\hline $2005 / 2006$ & \multicolumn{2}{|l|}{7.8} & 460 & \multicolumn{2}{|l|}{7.9} & 485 & \multicolumn{2}{|l|}{7.4} & 490 & \multicolumn{2}{|l|}{8.0} & 490 \\
\hline $2006 / 2007$ & \multicolumn{2}{|l|}{10.1} & 620 & \multicolumn{2}{|l|}{10.3} & 640 & \multicolumn{2}{|l|}{9.7} & 610 & \multicolumn{2}{|l|}{10.3} & 570 \\
\hline $2007 / 2008$ & 8.7 & & 490 & \multicolumn{2}{|l|}{8.7} & 440 & \multicolumn{2}{|l|}{8.6} & 460 & \multicolumn{2}{|l|}{8.9} & 960 \\
\hline $2008 / 2009$ & \multicolumn{3}{|l|}{8.2} & \multicolumn{2}{|l|}{8.5} & 430 & \multicolumn{2}{|l|}{8.1} & 580 & \multicolumn{2}{|l|}{8.6} & 670 \\
\hline Soil & \multicolumn{3}{|l|}{ Silty loam } & \multicolumn{3}{|c|}{ Loam } & \multicolumn{3}{|c|}{ Sandy loam } & Silty & oam & \\
\hline Wheat cultivar & Cubus & & & Trend & & & Tona & & & Smug & & \\
\hline Preceding crop & $\begin{array}{l}\text { Winter oilsee } \\
\text { napus L. va }\end{array}$ & $\begin{array}{l}\text { ed ral } \\
\text { ar. } n c\end{array}$ & $\begin{array}{l}\text { apus) } \\
\text { apsica }\end{array}$ & Winte & oilsee & rape & $\begin{array}{r}\text { Wint } \\
\text { Wint } \\
200\end{array}$ & $\begin{array}{l}\text { r wheat } \\
\text { r oilseec } \\
9\end{array}$ & $\begin{array}{l}-2006,2007 \\
\text { rape }-2008\end{array}$ & Winte & $r$ oilsee & rape \\
\hline Pre-preceding crop & $\begin{array}{r}\text { Spring barley } \\
\text { vulgare } \mathrm{L} .)\end{array}$ & y $(H c$ & rdeum & Sprin & barley & & $\begin{array}{r}\text { Whit } \\
\text { alb }\end{array}$ & $\begin{array}{l}\text { mustar } \\
\text { L.) }-2\end{array}$ & $\begin{array}{l}\text { d (Sinapis } \\
006,2007\end{array}$ & $\begin{array}{r}\text { Tritic } \\
\text { Wit } \\
200\end{array}$ & $\begin{array}{l}\text { le }(\times T r \\
\text { m. ex } A \\
6,2007\end{array}$ & $\begin{array}{l}\text { iticosecale } \\
2008\end{array}$ \\
\hline & & & & & & & Sprin & g barley & - 2008, 2009 & Sprin & wheat & -2009 \\
\hline $\begin{array}{l}\text { Level of mineral } \\
\quad \text { fertilization, } \mathrm{kg} \cdot \mathrm{ha}^{-1}\end{array}$ & $\mathrm{~N}$ & $\mathrm{P}$ & $\mathrm{K}$ & $\mathrm{N}$ & $\mathrm{P}$ & $\mathrm{K}$ & $\mathrm{N}$ & $\mathrm{P}$ & $\mathrm{K}$ & $\mathrm{N}$ & $\mathrm{P}$ & $\mathrm{K}$ \\
\hline 2006 & 101 & 28 & 59 & 103 & 25 & 47 & 80 & 17 & 50 & 102 & 21 & 81 \\
\hline 2007 & 106 & 36 & 54 & 105 & 25 & 47 & 80 & 17 & 50 & 107 & 23 & 87 \\
\hline 2008 & 108 & 31 & 46 & 0 & 0 & 0 & 80 & 17 & 50 & 105 & 18 & 83 \\
\hline 2009 & 98 & 24 & 66 & 108 & 25 & 47 & 80 & 17 & 50 & 105 & 18 & 83 \\
\hline Fungicide $^{\mathrm{a}}$ application & & & & & & & & & & & & \\
\hline 2006 & $\begin{array}{l}\text { GS } 30-31^{2} \\
\text { GS } 49-59\end{array}$ & $\begin{array}{l}\text { Aler } \\
\text { Falc }\end{array}$ & $\begin{array}{l}\text { t } 375 \mathrm{SC} \\
\text { on } 460 \mathrm{EC}\end{array}$ & $\begin{array}{l}\text { Chari } \\
\text { Amis }\end{array}$ & $\begin{array}{l}\text { na } 20 \\
\text { r } 250\end{array}$ & $\begin{array}{l}\text { EC } \\
\text { SC }\end{array}$ & $\begin{array}{l}\text { Alert } \\
\text { Artea }\end{array}$ & $\begin{array}{l}375 \mathrm{SC} \\
330 \mathrm{EC}\end{array}$ & & $\begin{array}{l}\text { Alleg } \\
\text { Amis }\end{array}$ & $\begin{array}{l}\operatorname{ar} 250 \\
\operatorname{ar} 250\end{array}$ & \\
\hline 2007 & $\begin{array}{l}\text { GS } 30-31 \\
\text { GS } 49-59\end{array}$ & $\begin{array}{l}\text { Alle } \\
\text { Falc }\end{array}$ & $\begin{array}{l}\text { gro } 250 \mathrm{SC} \\
\text { on } 460 \mathrm{EC}\end{array}$ & $\begin{array}{l}\text { Juwel } \\
\text { Amis }\end{array}$ & $\begin{array}{l}\text { ГT } 48 \\
\text { r } 250\end{array}$ & $\begin{array}{l}\text { SE } \\
\text { SC }\end{array}$ & $\begin{array}{l}\text { Alert } \\
\text { Artea }\end{array}$ & $\begin{array}{l}375 \mathrm{SC} \\
330 \mathrm{EC}\end{array}$ & & $\begin{array}{l}\text { Juwel } \\
\text { Amis }\end{array}$ & $\begin{array}{l}\text { TT } 48 \\
\operatorname{ar} 250\end{array}$ & \\
\hline 2008 & $\begin{array}{l}\text { GS } 30-31 \\
\text { GS } 49-59\end{array}$ & $\begin{array}{l}\text { Juw } \\
\text { Ami }\end{array}$ & $\begin{array}{l}\text { el TT } 483 \mathrm{SE} \\
\text { star } 250 \mathrm{SC}\end{array}$ & $\begin{array}{l}\text { None } \\
\text { None }\end{array}$ & & & $\begin{array}{l}\text { Alert } \\
\text { Artea }\end{array}$ & $\begin{array}{l}375 \mathrm{SC} \\
330 \mathrm{EC}\end{array}$ & & $\begin{array}{l}\text { Opera } \\
\text { Swing }\end{array}$ & $\begin{array}{l}\text { Max } 1 \\
\text { Top } 1\end{array}$ & $\begin{array}{l}47,5 \mathrm{SE} \\
3 \mathrm{SC}\end{array}$ \\
\hline 2009 & $\begin{array}{l}\text { GS } 30-31 \\
\text { GS } 49-59\end{array}$ & $\begin{array}{l}\text { Juw } \\
\text { Fanc }\end{array}$ & $\begin{array}{l}\text { el TT } 483 \text { SE } \\
\text { lango } 200 \mathrm{EC}\end{array}$ & $\begin{array}{l}\text { Opera } \\
\text { Fanda }\end{array}$ & $\begin{array}{l}\text { Max } 1 \\
\operatorname{go} 20\end{array}$ & $\begin{array}{l}47,5 \mathrm{SE} \\
\mathrm{EC}\end{array}$ & $\begin{array}{l}\text { Alert } \\
\text { Artea }\end{array}$ & $\begin{array}{l}375 \mathrm{SC} \\
330 \mathrm{EC}\end{array}$ & & $\begin{array}{l}\text { Wirtu } \\
\text { Chari } \\
\text { Talius }\end{array}$ & $\begin{array}{l}\text { oz } 520 \\
\text { sma } 20^{\prime} \\
200 \mathrm{EC}\end{array}$ & $\begin{array}{l}\mathrm{EC} \\
\mathrm{EC}\end{array}$ \\
\hline
\end{tabular}

${ }^{\text {a }}$ Fungicide active ingredients:

Alert $375 \mathrm{SC}\left(125 \mathrm{gl}^{-1}\right.$ flusilazole $+250 \mathrm{gl}^{-1}$ carbendazim), Du Pont de Nemours (France) S.A.S

Allegro $250 \mathrm{SC}$ (125 $\mathrm{gl}^{-1}$ kresoxim-methyl $+125 \mathrm{gl}^{-1}$ epoxiconazole), BASF SE Germany

Amistar $250 \mathrm{SC}$ (250 $\mathrm{gl}^{-1}$ azoxystrobin), Syngenta Crop Protection, Switzerland

Artea $330 \mathrm{EC}$ (250 $\mathrm{gl}^{-1}$ propiconazole $+80 \mathrm{gl}^{-1}$ cyproconazole), Syngenta Crop Protection, Switzerland

Charisma $207 \mathrm{EC}$ (106.7 $\mathrm{gl}^{-1}$ flusilazole $+100 \mathrm{gl}^{-1}$ famoxadone), DuPont Poland Sp. Z o.o

Falcon $460 \mathrm{EC}\left(250 \mathrm{gl}^{-1}\right.$ spiroxamine $+167 \mathrm{gl}^{-1}$ tebuconazole $+43 \mathrm{gl}^{-1}$ triadimenol), Bayer CropScience AG, Germany

Fandango $200 \mathrm{EC}\left(100 \mathrm{gl}^{-1}\right.$ prothioconazole $+100 \mathrm{gl}^{-1}$ fluoxastrobin), Bayer CropScience AG, Germany

Opera Max 147,5 SE (85 $\mathrm{gl}^{-1}$ pyraclostrobin $+62.5 \mathrm{gl}^{-1}$ epoxiconazole), BASF SE, Germany

Juwel TT $483 \mathrm{SE}\left(83 \mathrm{gl}^{-1}\right.$ epoxiconazole $+83 \mathrm{gl}^{-1}$ kresoxim-methyl $+317 \mathrm{gl}^{-1}$ fenpropimorph), BASF SE, Germany

Swing Top $183 \mathrm{SC}\left(133 \mathrm{gl}^{-1}\right.$ dimoxystrobin $+50 \mathrm{gl}^{-1}$ epoxiconazole), BASF SE, Germany

Talius $200 \mathrm{EC}$ (200 $\mathrm{gl}^{-1}$ proquinazid), DuPont Poland Sp. Z o.o

Wirtuoz $520 \mathrm{EC}\left(320 \mathrm{gl}^{-1}\right.$ prochloraz $+160 \mathrm{gl}^{-1}$ tebuconazole $+40 \mathrm{gl}^{-1}$ proquinazid), DuPont Poland Sp. Z o.o

${ }^{2}$ Fungicides were applied at the beginning of stem elongation (GS 30-31) and during heading (GS 49-59) 
Measurement of wheat yield

One hundred shoots from each crop were assessed for effects of sharp eyespot severity on yield. Plant and ear dry weights and the number of grains per ear were determined. Grain from individual ears was threshed, dried and weighed. Grain was separated into fractions according to length, i.e. $<2 \mathrm{~mm}, 2-2.5 \mathrm{~mm}, 2.5-$ $2.8 \mathrm{~mm}$ and $>2.8 \mathrm{~mm}$, and percentage of grains in each size category was determined for each sharp eyespot severity category. Thousand-grain weights were determined using 400 grains taken at random from a $500 \mathrm{~g}$ sample from each severity category. Germination rate of grain (\% seeds germinating) from each severity category was determined. The yield of grain from the sample area was determined.

Measurement of grain quality

Grain was evaluated for four technological traits: total protein and wet gluten contents, Hagberg falling number and sedimentation value. Hagberg falling number is an indicator of alpha-amylase activity in the flour. A high value indicates low alpha-amylase activity, showing that the flour is less degraded by the enzyme. Sedimentation value indicates the baking quality of flour. Higher values indicate better quality of total protein and strength of gluten. Each analysis was done twice, each time on 15-20 g of grain taken at random from each severity category.

Total protein content and sedimentation value were determined by near-infrared spectroscopy (NIR). Wet gluten content was determined by the standard procedure, PN-A-74043-2. This included preparation of dough (10 $\mathrm{g}$ of ground grain $+5.5 \mathrm{ml} 2 \% \mathrm{NaCl}$ ), extraction of wet gluten from the dough (by washing it out with $2 \% \mathrm{NaCl}$ ), removing excess water (by centrifuge) and weighing the dried mass of gluten. Hagberg falling number was determined by the standard procedure, PN-ISO-3093, which follows the ICC (International Association of Cereal Science and Technology) standard method No. 107.

Association of sharp eyespot with colonization of grain by other fungi

Colonization of grain by fungi was studied on samples taken from shoots with disease in severity categories 2 and 3, and healthy controls. One hundred grains, selected randomly from each sample, were rinsed in tap water for $45 \mathrm{~min}$, surfacedisinfected in sodium hypochlorite $(1 \%$ available chlorine) for $3 \mathrm{~min}$, rinsed $3 \times 10 \mathrm{~min}$ in sterile distilled water and placed on PDA $(\mathrm{pH}$ 5.5) in Petri dishes (six grains per plate). In 2007-2009 an additional 100 grains from the same disease categories were placed on PDA without rinsing or surface disinfection. After incubation for 10 days at $22{ }^{\circ} \mathrm{C}$, all cultures were transferred to PDA slants for preservation. Representative cultures were identified according to their morphology on potato dextrose agar (PDA; $40 \mathrm{~g}$ filtered white potatoes, $20 \mathrm{~g}$ agar, 11 distilled water, $\mathrm{pH}=7$ ) and synthetic nutrient agar (SNA; $1 \mathrm{~g} \mathrm{KH}_{2} \mathrm{PO}_{4}$, $1 \mathrm{~g} \mathrm{KNO}_{3}, 0.5 \mathrm{~g} \mathrm{MgSO}_{4} \cdot 7 \mathrm{H}_{2} \mathrm{O}, 0.5 \mathrm{~g} \mathrm{KCl}, 0.2 \mathrm{~g}$ glucose, $0.2 \mathrm{~g}$ sucrose, $20 \mathrm{~g}$ agar, $10 \mathrm{mg}$ chlorotetracycline, $50 \mathrm{mg}$ dihydrostreptomycin sulphate, 11 distilled water) and available literature. Some dematiaceous hyphomycetes were induced to sporulate under UV light (310-420 nm for $12 \mathrm{~h} /$ day) at $20{ }^{\circ} \mathrm{C}$, or on $2 \%$ MEA at $5{ }^{\circ} \mathrm{C}$ in high humidity, for 12-15 months. Fungi recorded from non-disinfected grains were considered to have grown, at least partly, from the surface of the grains, and those recorded from surfacedisinfected grains were considered to have grown from inside of the grain. The identity of Fusarium langsethiae was confirmed by PCR assay with the use of SCAR (sequence characterized amplified region) primers (Wilson et al. 2004).

\section{Statistical analyses}

Data for sharp eyespot incidence and all plant growth, grain yield and grain quality measurements, logtransformed where appropriate, were subjected to one-way or three-way analysis of variance (ANOVA, Huynh and Feldt 1970). Where interactions (severity $\times$ location and severity $\times$ year) occurred, data were (i) plotted to determine the factors responsible, and (ii) subjected to Scheffé's method (Maxwell and Delaney 1990) for estimation of significance of the differences between averages. Where there were no factorial interactions, the data are discussed individually. Statistical significance was assumed at $P \leq 0.05$ or $P \leq 0.001$ using Matlab 7.3.0 with Statistical Toolbox version 5.3 (MathWorks, Inc., Natick, MA, USA). The statistical 
significance of difference between numbers of fungal isolates from two different grain samples was determined by a $\chi^{2}$ - test according to the formula

$\chi^{2}=\left(\mathrm{n}_{i}-\mathrm{nP}_{i}\right)^{2} / \mathrm{nP}_{i} \quad i=1$

where $\mathrm{n}$ is the number of isolates and $\mathrm{P}$ the probability of occurrence.

\section{Results}

Survey and sharp eyespot assessment

Sharp eyespot was recorded in crops surveyed in Chrzastowo, Minikowo, Mochełek and Sobiejuchy, in north-central Poland, in four successive years (Table 2). The progress of disease in individual sites and years, represented by the percentage of diseased stems in a sample of healthy + diseased plants, is shown in Fig. 2. In the sample that included healthy + diseased plants, average percentage of shoots in different disease categories was: (13.7-) 32.3-58.1 (-84.6) in category 0; (11.6-) 16.7-36.3 (-49.0) in category 1 ; (3.2-) 10.9$23.7(-30.2)$ in category 2 ; $(0-)$ 2.6-11.5 (-35.6) in category 3 . In the sample that included only diseased plants, symptoms developed on $49-73.5 \%$ of shoots. Average percentage of shoots infected was: (12.2-) 26.5-51.0 (-70.4) in category 0 ; (14.8-) 24.4-41.3 $(-51.3)$ in category 1 ; (8.9-) 16.9-25.5 (-32.4) in category 2 ; (0) 3.2-7.1 (-22.0) in category 3 (Table 2 ). The

Table 2 Percentage of shoots with sharp eyespot in different severity categories in healthy + diseased plants (A) and diseased plants (B) and the yield of grain from the sample area

\begin{tabular}{|c|c|c|c|c|c|c|c|c|c|c|c|}
\hline & \multicolumn{2}{|c|}{ No. of stems examined } & \multicolumn{8}{|c|}{ Severity category } & \multirow{3}{*}{$\begin{array}{l}\text { Yield of grain }\left(\mathrm{t} \cdot \mathrm{ha}^{-1}\right) \\
\text { B }\end{array}$} \\
\hline & & & \multicolumn{2}{|l|}{0} & \multicolumn{2}{|l|}{1} & \multicolumn{2}{|l|}{2} & \multicolumn{2}{|l|}{3} & \\
\hline & $\mathrm{A}$ & $\mathrm{B}$ & $\mathrm{A}$ & $\mathrm{B}$ & $\mathrm{A}$ & $\mathrm{B}$ & A & $\mathrm{B}$ & $\mathrm{A}$ & $\mathrm{B}$ & \\
\hline \multicolumn{12}{|l|}{ Chrząstowo } \\
\hline 2006 & 774 & 696 & 64.3 & 70.4 & 18.3 & 14.8 & 17.4 & 14.8 & 0.0 & 0.0 & 6.81 \\
\hline 2007 & 821 & 581 & 17.2 & 12.2 & 24.8 & 34.6 & 22.4 & 31.2 & 35.6 & 22.0 & 6.98 \\
\hline 2008 & 1089 & 314 & 84.6 & 57.4 & 12.2 & 33.4 & 3.2 & 9.2 & 0.0 & 0.0 & 7.96 \\
\hline 2009 & 809 & 609 & 66.4 & 63.8 & 11.6 & 14.9 & 11.6 & 14.9 & 10.4 & 6.4 & 8.15 \\
\hline Average in 2006-2009 & 873 & 550 & 58.1 & 51.0 & 16.7 & 24.4 & 13.7 & 17.5 & 11.5 & 7.1 & 7.48 \\
\hline \multicolumn{12}{|l|}{ Minikowo } \\
\hline 2006 & 760 & 715 & 63.1 & 63.7 & 18.9 & 19.2 & 18.0 & 17.1 & 0.0 & 0.0 & 6.81 \\
\hline 2007 & 900 & 474 & 58.0 & 39.0 & 18.0 & 32.5 & 16.2 & 19.0 & 7.8 & 9.5 & 6.94 \\
\hline 2009 & 784 & 443 & 53.0 & 44.2 & 36.9 & 41.1 & 10.1 & 14.7 & 0.0 & 0.0 & 7.93 \\
\hline Average in $2006-2009$ & 815 & 544 & 58.0 & 49.0 & 24.6 & 30.9 & 14.8 & 16.9 & 2.6 & 3.2 & 7.23 \\
\hline \multicolumn{12}{|l|}{ Mochełek } \\
\hline 2006 & 800 & 554 & 56.9 & 44.4 & 25.9 & 33.0 & 12.8 & 19.0 & 4.4 & 3.6 & 4.17 \\
\hline 2007 & 722 & 643 & 28.2 & 28.2 & 47.9 & 51.3 & 14.3 & 13.7 & 9.6 & 6.8 & 3.86 \\
\hline 2008 & 860 & 485 & 61.1 & 49.5 & 30.3 & 37.1 & 5.2 & 8.9 & 3.4 & 4.5 & 3.81 \\
\hline 2009 & 1028 & 509 & 54.3 & 31.4 & 16.6 & 31.4 & 11.4 & 28.9 & 17.7 & 8.3 & 3.94 \\
\hline Average in 2006-2009 & 853 & 548 & 50.1 & 38.4 & 30.2 & 38.2 & 10.9 & 17.6 & 8.8 & 5.8 & 3.95 \\
\hline \multicolumn{12}{|l|}{ Sobiejuchy } \\
\hline 2006 & 791 & 336 & 63.0 & 39.5 & 18.0 & 41.7 & 10.0 & 12.5 & 9.0 & 6.3 & 7.85 \\
\hline 2007 & 795 & 712 & 28.7 & 30.3 & 36.4 & 37.4 & 26.7 & 26.7 & 8.2 & 5.6 & 7.99 \\
\hline 2008 & 764 & 616 & 13.7 & 16.4 & 49.0 & 44.2 & 30.2 & 32.4 & 7.1 & 7.0 & 8.11 \\
\hline 2009 & 792 & 504 & 23.9 & 19.8 & 42.0 & 41.9 & 27.8 & 30.4 & 6.3 & 7.9 & 8.32 \\
\hline Average in 2006-2009 & 786 & 542 & 32.3 & 26.5 & 36.3 & 41.3 & 23.7 & 25.5 & 7.7 & 6.7 & 8.08 \\
\hline \multicolumn{3}{|c|}{ Average of all locations and years } & 49.6 & 41.2 & 27.0 & 33.7 & 15.8 & 19.4 & 7.7 & 5.7 & 6.68 \\
\hline
\end{tabular}


Fig. 2 Incidence of the sharp eyespot in Chrzastowo, Minikowo, Mochełek and Sobiejuchy in 2006-2009

proportions of main shoots and secondary tillers infected were similar. The highest proportions of shoots infected were in the least severe disease categories. The most severe disease occurred at three sites in 2007 and was associated with highest average temperature and total precipitation (Fig. 2, Table 1). The higher average temperature in 2006/2007 resulted from a relatively warm and wet autumn and winter and following spring, but relatively cool and wet summer. The generally greater amount of disease at Sobiejuchy in 2006-2008 was associated with most grain yield $\left(8.08\right.$ tha $\left.^{-1}\right)$. Mixed symptoms of sharp eyespot and other diseases such as true eyespot were found rarely.

\section{Detection of Rhizoctonia cerealis}

Growth rate in vitro and morphology of mycelium isolated from lesions, identified as sharp eyespot, conformed to the original description of $R$. cerealis. The taxonomy of $R$. cerealis was confirmed additionally with PCR. The specific $R$. cerealis primer, SCAR Rc2 F/R type, amplified DNA from wheat leaf sheath and stem base samples and from the isolated mycelium giving a DNA product of $800-\mathrm{bp}$. Koch's postulates were satisfied by re-infection and re-isolation of the pathogen. In pathogenicity tests, 7-16 days after reinfection, most isolates of $R$. cerealis produced lesions typical of sharp eyespot on the wheat coleoptiles, stems, leaves and sometimes on roots. Stem infection caused the plants to die eventually. Mycelium was isolated from the leading edge of developing rachis lesions. Its colony morphology and hyphal branching were consistent with the applied $R$. cerealis.

Grain yield and quality

Increasing severity of sharp eyespot generally decreased plant and ear dry weights, number of grains per ear, grain dry weight per ear and thousand-grain weight (Table 3). Greatest effects were usually observed at Minikowo and Mochełek. Grain variates were often affected, with statistical significance, by sharp eyespot severity category (0-3), location (Ch, Mi, Mo, So), and year (2006, 2007, 2008, 2009) (Table 4). Factorial interactions, severity $\times$ location and severity $\times$ year, were also sometimes significant.
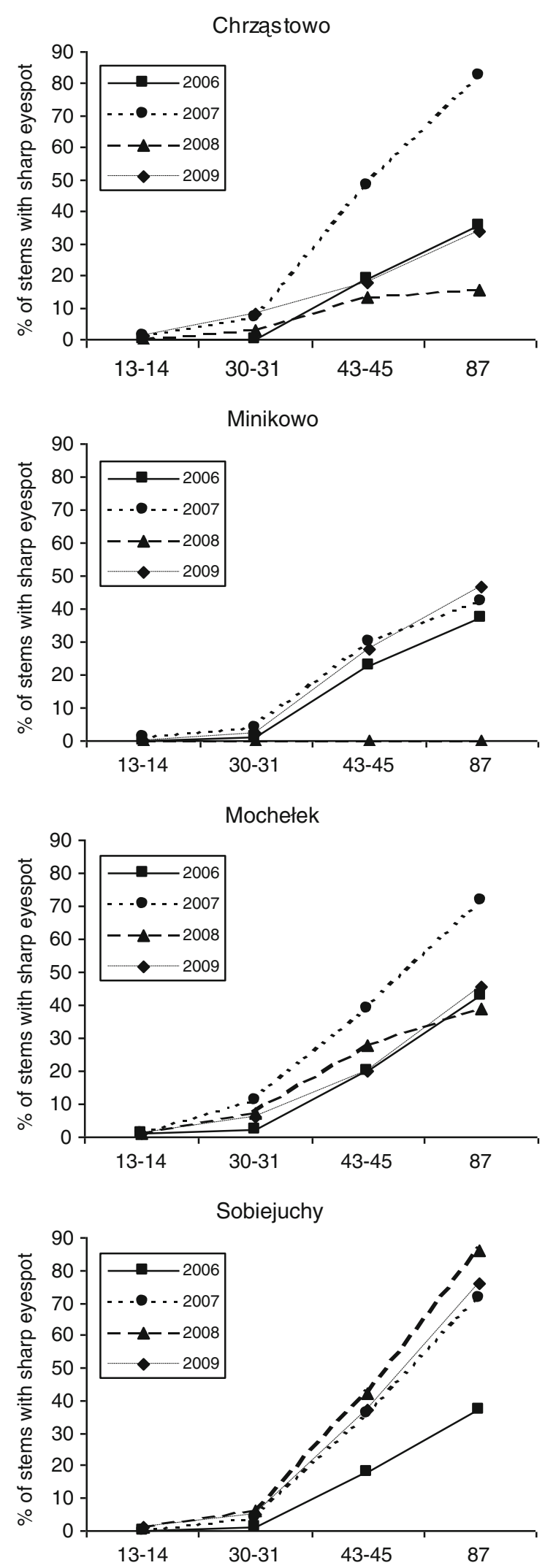


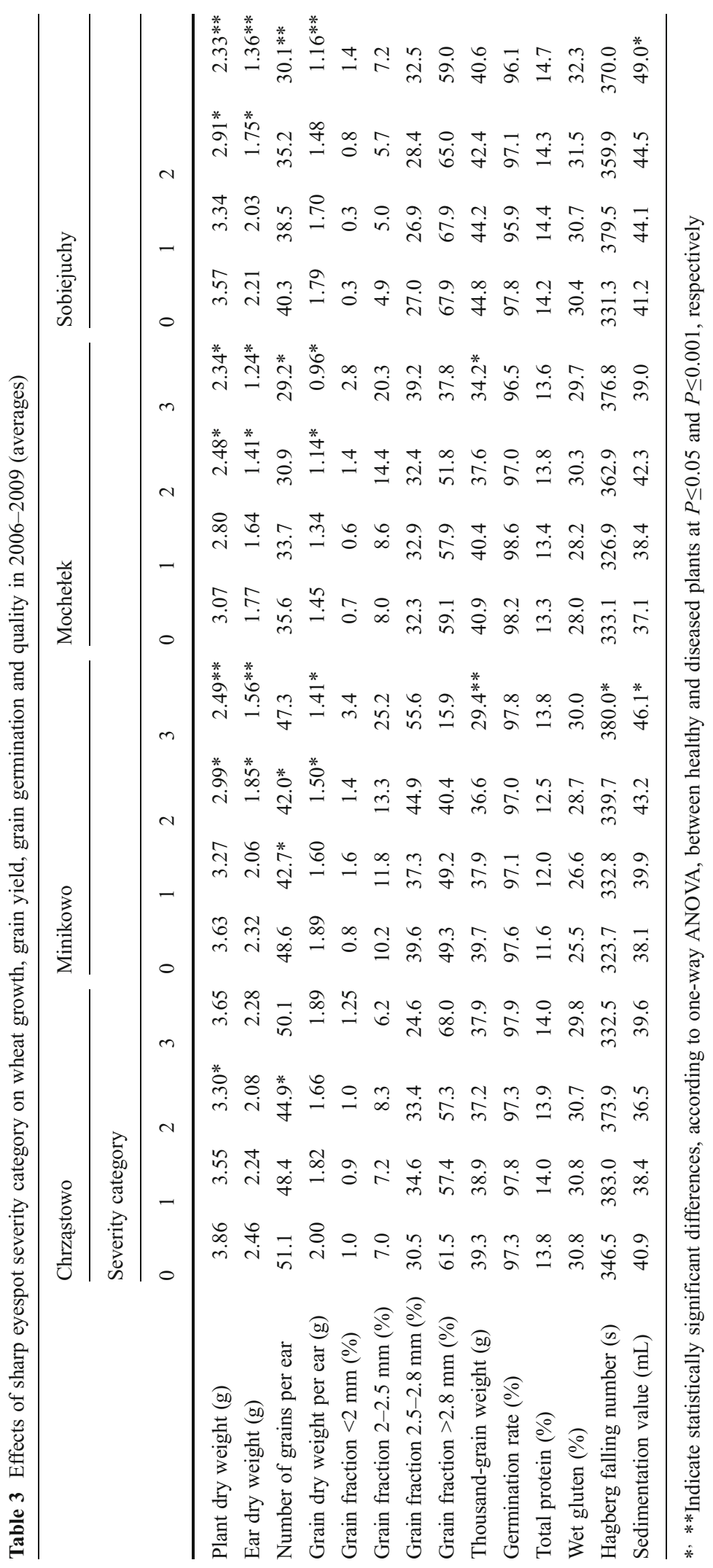


Table 4 Summary of effects of sharp eyespot severity category (0-3), location (Ch, Mi, Mo, So) and year (2006, 2007, 2008, 2009) on grain yield and quality

\begin{tabular}{llllll}
\hline Variate & Severity category & Location & Year & Interactions \\
\cline { 3 - 6 } & & & & Severity $\times$ Location & Severity $\times$ Year \\
\hline Number of grains per ear & $0^{\mathrm{a}} 1^{\mathrm{b}} 2^{\mathrm{c}} 3^{\mathrm{c}}$ & $\mathrm{Ch}^{\mathrm{a}} \mathrm{Mi}^{\mathrm{b}} \mathrm{So}^{\mathrm{c}} \mathrm{Mo}^{\mathrm{d}}$ & $07^{\mathrm{a}} 09^{\mathrm{a}} 06^{\mathrm{b}} 08^{\mathrm{c}}$ & $\mathrm{ns}$ & $\mathrm{ns}$ \\
Plant dry weight & $0^{\mathrm{a}} 1^{\mathrm{b}} 2^{\mathrm{c}} 3^{\mathrm{d}}$ & $\mathrm{Ch}^{\mathrm{a}} \mathrm{Mi}^{\mathrm{b}} \mathrm{So}^{\mathrm{b}} \mathrm{Mo}^{\mathrm{c}}$ & $09^{\mathrm{a}} 07^{\mathrm{a}} 08^{\mathrm{b}} 06^{\mathrm{c}}$ & $P=0.0017$ & $P=0.0032$ \\
Ear dry weight & $0^{\mathrm{a}} 1^{\mathrm{b}} 2^{\mathrm{c}} 3^{\mathrm{d}}$ & $\mathrm{Ch}^{\mathrm{a}} \mathrm{Mi}^{\mathrm{b}} \mathrm{So}^{\mathrm{b}} \mathrm{Mo}^{\mathrm{c}}$ & $09^{\mathrm{a}} 07^{\mathrm{b}} 08^{\mathrm{c}} 06^{\mathrm{c}}$ & $P=0.0137$ & $\mathrm{~ns}$ \\
Grain dry weight per ear & $0^{\mathrm{a}} 1^{\mathrm{b}} 2^{\mathrm{c}} 3^{\mathrm{c}}$ & $\mathrm{Ch}^{\mathrm{a}} \mathrm{Mi}^{\mathrm{b}} \mathrm{So}^{\mathrm{b}} \mathrm{Mo}^{\mathrm{c}}$ & $09^{\mathrm{a}} 07^{\mathrm{b}} 08^{\mathrm{bc}} 06^{\mathrm{c}}$ & $P=0.0124$ & $\mathrm{~ns}$ \\
Thousand grain weight & $0^{\mathrm{a}} 1^{\mathrm{a}} 2^{\mathrm{b}} 3^{\mathrm{b}}$ & $\mathrm{So}^{\mathrm{a}} \mathrm{Ch}^{\mathrm{b}} \mathrm{Mo}^{\mathrm{b}} \mathrm{Mi}^{\mathrm{b}}$ & $08^{\mathrm{a}} 09^{\mathrm{b}} 07^{\mathrm{c}} 06^{\mathrm{c}}$ & $P=0.0075$ & $\mathrm{~ns}$ \\
Germination rate & $0^{\mathrm{a}} 1^{\mathrm{ab}} 2^{\mathrm{ab}} 3^{\mathrm{b}}$ & $\mathrm{Mo}^{\mathrm{a}} \mathrm{Ch}^{\mathrm{ab}} \mathrm{So}^{\mathrm{b}} \mathrm{Mi}^{\mathrm{b}}$ & $07^{\mathrm{a}} 06^{\mathrm{b}} 09^{\mathrm{b}} 08^{\mathrm{c}}$ & $P=0.0037$ & $\mathrm{~ns}$ \\
Protein content & - & $\mathrm{So}^{\mathrm{a}} \mathrm{Ch}^{\mathrm{ab}} \mathrm{Mo}^{\mathrm{b}} \mathrm{Mi}^{\mathrm{c}}$ & - & $\mathrm{ns}^{\mathrm{a}}$ & $\mathrm{ns}$ \\
Wet gluten content & $0^{\mathrm{a}} 1^{\mathrm{ab}} 2^{\mathrm{ab}} 3^{\mathrm{b}}$ & $\mathrm{So}^{\mathrm{a}} \mathrm{Ch}^{\mathrm{a}} \mathrm{Mo}^{\mathrm{b}} \mathrm{Mi}^{\mathrm{b}}$ & $06^{\mathrm{a}} 08^{\mathrm{a}} 07^{\mathrm{b}} 09^{\mathrm{b}}$ & $\mathrm{ns}$ & $\mathrm{ns}$ \\
Hagberg falling number & $0^{\mathrm{a}} 1^{\mathrm{ab}} 2^{\mathrm{ab}} 3^{\mathrm{b}}$ & - & $06^{\mathrm{a}} 08^{\mathrm{ab}} 09^{\mathrm{b}} 07^{\mathrm{c}}$ & $\mathrm{ns}$ & $\mathrm{ns}$ \\
Sedimentation value & - & $\mathrm{So}^{\mathrm{a}} \mathrm{Mi}^{\mathrm{ab}} \mathrm{Ch}^{\mathrm{b}} \mathrm{Mo}^{\mathrm{b}}$ & $06^{\mathrm{a}} 07^{\mathrm{b}} 09^{\mathrm{b}} 08^{\mathrm{b}}$ & $\mathrm{ns}$ & \\
\hline
\end{tabular}

a, b, c, d Different letters indicate statistically significant differences, according to three-way ANOVA at $P \leq 0.05$

ns no significant interactions

There were no significant interactions of severity category $\times$ location on number of grains per ear, or of severity category $\times$ year on number of grains per ear, ear dry weight, grain dry weight per ear or thousandgrain weight. Percentage of grains in small fractions ( $<2 \mathrm{~mm}, 2-2.5 \mathrm{~mm}, 2.5-2.8 \mathrm{~mm}$ ) often increased, and in larger fractions $(>2.8 \mathrm{~mm})$ decreased, with increased severity category. Sharp eyespot did not usually affect grain germination.

Increasing severity of sharp eyespot increased, but usually not significantly, protein and wet gluten contents in grain, and Hagberg falling number and sedimentation value (Table 3). Location significantly affected protein content, while severity category, location and year often significantly affected wet gluten content, Hagberg falling number and sedimentation value (Table 4).

\section{Colonization of grain by fungi}

Occurrence of sharp eyespot was associated with increased colonization of grain by fungi. On average there were 2.4-4.0 and 2.7-4.4 fungal isolates per grain from healthy and diseased plants, respectively, and 2.4-4.4 and 3.3-4.1 fungal isolates per grain from grain surface (non-disinfected) and interior (surface-disinfected), respectively (Table 5). Alternaria alternata and Epicoccum nigrum were the most common fungi. Both fungi occurred significantly more often on healthy plants only at Minikowo. Arthrinium phaeospermum, Aspergillus niger, Botrytis cinerea, E. nigrum, Fusarium culmorum, Gibberella zeae, Khuskia oryzae, Microdochium bolleyi, Mucor mucedo, Penicillium granulatum and Trichoderma viride occurred more often on the grain surface, and A. alternata Cladosporium herbarum and Cochliobolus sativus more often inside grain. Cladosporium herbarum and Gibberella tricincta tended to occur (but not significantly) more often in/on grain from healthy plants, and Fusarium poae, K. oryzae, M. bolleyi and $T$. viride on grain from diseased plants. The latter fungi seemed to be secondary colonizers which take advantage of the weakened tissue. Fusarium langsethiae occurred only inside grain. Its identity was confirmed by PCR amplification of DNA with SCAR primer, which produced the diagnostic 310-bp DNA fragment.

\section{Discussion}

A recent increase in sharp eyespot in cereals, including winter wheat, in Poland has been observed (Kurowski and Adamiak 2007; Lemańczyk 2010a, b). The situation in Poland resembles that in the Netherlands where, from 1974 to 1986, sharp eyespot increased in prevalence annually by an average of $0.4 \%$ of culms and $4 \%$ of fields affected (Daamen and Stol 1990). The disease has also become gradually more 
Table 5 The most commonly occurring fungi on wheat grain from healthy stems and stems with sharp eyespot

\begin{tabular}{|c|c|c|c|c|c|c|c|c|c|c|c|c|c|c|c|c|}
\hline \multirow[t]{4}{*}{ Taxon } & \multicolumn{8}{|c|}{ Non-disinfected grain (2007-2009) } & \multicolumn{8}{|c|}{ Surface-disinfected grain (2006-2009) } \\
\hline & \multicolumn{2}{|c|}{ Chrząstowo } & \multicolumn{2}{|c|}{ Minikowo } & \multicolumn{2}{|c|}{ Mochełek } & \multicolumn{2}{|c|}{ Sobiejuchy } & \multicolumn{2}{|c|}{ Chrząstowo } & \multicolumn{2}{|c|}{ Minikowo } & \multicolumn{2}{|c|}{ Mochełek } & \multicolumn{2}{|c|}{ Sobiejuchy } \\
\hline & & $\mathrm{D}^{\mathrm{b}}$ & $\mathrm{H}$ & $\mathrm{D}$ & $\mathrm{H}$ & $\mathrm{D}$ & $\mathrm{H}$ & $\mathrm{D}$ & $\mathrm{H}$ & $\mathrm{D}$ & $\mathrm{H}$ & $\mathrm{D}$ & $\mathrm{H}$ & $\mathrm{D}$ & $\mathrm{H}$ & $\mathrm{D}$ \\
\hline & \multicolumn{16}{|c|}{ Percentage of total number of isolates } \\
\hline $\begin{array}{l}\text { Alternaria alternata } \\
\text { (Fr.) Keissl. }\end{array}$ & 45.5 & 44.3 & $33.1 *$ & $12.8 *$ & 44.7 & 36.7 & 36.6 & 44.6 & 65.2 & 57.8 & 36.0 & 46.7 & 53.6 & 56.0 & 57.5 & 57.8 \\
\hline $\begin{array}{l}\text { Arthrinium phaeospermum } \\
\text { (Corda) M.B. Ellis }\end{array}$ & 0.2 & 0.5 & 0.8 & 0.4 & 1.3 & 0.2 & 1.0 & 0 & 0.3 & 1.1 & 0 & 0.6 & 0.3 & 0 & 0 & 0 \\
\hline Aspergillus niger Tiegh. & 2.0 & 0.9 & 2.9 & 0.8 & 3.7 & 1.7 & 2.0 & 0.8 & 0 & 1.9 & 0 & 0.3 & 1.0 & 0.5 & 1.4 & 2.9 \\
\hline Botrytis cinerea Pers. & 7.0 & 3.7 & 0.8 & 0.8 & 0.3 & 3.0 & 1.3 & 2.0 & 0 & 1.4 & 1.5 & 0.9 & 0.3 & 0.5 & 0.5 & 0.3 \\
\hline $\begin{array}{l}\text { Cladosporium herbarum } \\
\text { (Pers.) Link }\end{array}$ & 0 & 0.5 & 0 & 0 & 0.3 & 0.5 & 0 & 0.3 & 5.0 & 3.1 & 14.6 & 11.1 & 4.6 & 8.8 & 3.3 & 0.3 \\
\hline $\begin{array}{l}\text { Cochliobolus sativus } \\
\text { (S. Ito \& Kurib.) } \\
\text { Drechsler ex Dastur }\end{array}$ & 0 & 0 & 0 & 0 & 0.5 & 1.2 & 0.3 & 0 & 0 & 2.8 & 0 & 0 & 0.5 & 0.2 & 0.8 & 0.6 \\
\hline Epicoccum nigrum Link & 23.4 & 20.5 & $37.6^{*}$ & $22.6^{*}$ & 25.9 & 25.1 & 16.8 & 22.1 & 17.3 & 14.7 & 22.0 & 18.1 & 21.9 & 15.9 & 16.3 & 16.3 \\
\hline $\begin{array}{l}\text { Fusarium culmorum } \\
\text { (W.G. Sm.) Sacc. }\end{array}$ & 7.0 & 7.5 & 0 & 0.8 & 0 & 0 & 3.5 & 4.8 & 0.3 & 0.3 & 0 & 0 & 0 & 0 & 3.0 & 0.3 \\
\hline $\begin{array}{l}\text { Fusarium langsethiae } \\
\text { Torp \& Nirenberg }\end{array}$ & 0 & 0 & 0 & 0 & 0 & 0 & 0 & 0 & 0 & 0 & 1.2 & 0.9 & 0 & 0 & 0.3 & 0.3 \\
\hline $\begin{array}{l}\text { Fusarium poae } \\
\text { (Peck) Wollenw. }\end{array}$ & 2.7 & 4.3 & 8.3 & 9.8 & 1.6 & 3.0 & 1.3 & 1.0 & 1.4 & 2.5 & 11.0 & 8.1 & 3.6 & 2.7 & 0.8 & 1.7 \\
\hline $\begin{array}{l}\text { Gibberella avenacea } \\
\text { R.J. Cook }\end{array}$ & 1.2 & 0.5 & 0.8 & 0 & 0.5 & 1.2 & 1.0 & 1.8 & 1.7 & 0.3 & 0.9 & 2.7 & 1.0 & 0 & 2.2 & 0.9 \\
\hline $\begin{array}{l}\text { Gibberella tricincta } \\
\text { El-Gholl, McRitchie, } \\
\text { Schoult. \& Ridings }\end{array}$ & 0 & 0.2 & 7.0 & 5.3 & 1.1 & 1.0 & 0 & 1.0 & 0 & 0.3 & 8.9 & 5.1 & 0.3 & 0.2 & 0 & 0.3 \\
\hline $\begin{array}{l}\text { Gibberella zeae (Schwein.) } \\
\text { Petch }\end{array}$ & 1.7 & 0.9 & 2.1 & 0.4 & 0.5 & 0 & 1.8 & 0.8 & 1.9 & 1.1 & 0 & 1.2 & 0 & 0 & 1.6 & 0 \\
\hline Khuskia oryzae H.J. Huds. & 0.5 & 0 & 2.1 & 0.8 & 1.9 & 7.4 & 2.5 & 6.8 & 0.6 & 0 & 0.3 & 0.6 & 3.9 & 4.2 & 4.4 & 4.7 \\
\hline $\begin{array}{l}\text { Melanospora damnosa } \\
\text { (Sacc.) Lindau }\end{array}$ & 1.0 & 5.0 & 0.4 & 0 & 1.1 & 1.2 & 2.0 & 1.0 & 0.3 & 0 & 0 & 0.6 & 0.3 & 0 & 0.3 & 1.2 \\
\hline $\begin{array}{l}\text { Microdochium bolleyi } \\
\text { (R. Sprague) de Hoog \& } \\
\text { Herm.-Nijh. }\end{array}$ & 4.5 & 6.8 & 0 & 0 & 7.0 & 9.4 & 7.0 & 10.0 & 2.2 & 5.0 & 0.6 & 0 & 7.5 & 5.9 & 3.8 & 5.5 \\
\hline Muсоr muсеdo Fresen. & 0.5 & 0.5 & 0 & 0 & 1.3 & 0.7 & 0.3 & 0.3 & 0 & 0 & 0 & 0 & 0 & 0.2 & 0 & 0 \\
\hline $\begin{array}{l}\text { Penicillium granulatum } \\
\text { Bainier }\end{array}$ & 0 & 0 & 0 & 38.5 & 0 & 0 & 19.3 & 0.5 & 0.3 & 0 & 0 & 0 & 0 & 0 & 2.7 & 0.3 \\
\hline Penicillium spp. & 1.5 & 2.7 & 1.7 & 0 & 6.4 & 6.4 & 1.0 & 0.8 & 0.6 & 5.0 & 1.5 & 2.1 & 0 & 2.9 & 0 & 5.2 \\
\hline Trichoderma viride Pers. & 0 & 0 & 0 & 6.8 & 0.5 & 0 & 1.5 & 0.8 & 0 & 0.8 & 0 & 0.3 & 0 & 0.2 & 0 & 0 \\
\hline Non-sporulating mycelia & 0.2 & 0.5 & 0.4 & 0 & 0.8 & 0.7 & 0.5 & 0 & 1.7 & 1.7 & 0.3 & 0.3 & 0.8 & 0 & 0.8 & 0.3 \\
\hline \multicolumn{17}{|l|}{ Number of isolates per grain } \\
\hline & 4.0 & 4.4 & 2.4 & 2.7 & 3.7 & 4.1 & 4.0 & 4.0 & 3.6 & 3.6 & 3.4 & 3.3 & 3.9 & 4.1 & 3.7 & 3.4 \\
\hline
\end{tabular}

${ }^{\mathrm{a}}$ Grain from healthy shoots

${ }^{\mathrm{b}}$ Grain from diseased shoots

*Indicate statistically significant differences, according to $\chi^{2}$ - tests, between healthy and diseased plants at $P=0.05$

Fungi with frequency $<1 \%$ : on grain from healthy plants: Aspergillus fumigatus Fresen., Gibberella intricans Wollenw. and on grain from diseased stems and healthy plants: Chaetomium funicola Cooke, Fusarium sporotrichioides Sherb., Gelasinospora cerealis Dowding, Ulocladium consortiale (Thüm.) E.G. Simmons, Stemphylium sp., on grain from diseased stems: Drechslera triseptata (Drechsler) Subram. \& B.L. Jain, Pyrenophora erythrospila A.R. Paul 
severe in wheat and grass cropping areas of China, Italy, Russia, Turkey, Ukraine and the United Kingdom (Rossi et al. 1995; Colbach et al. 1997; Etheridge et al. 2001; Kryuchkova 2000; Tunali et al. 2008; Zhalieva 2008; Chen et al. 2010). Although sharp eyespot is not currently a major yield-limiting disease of wheat, considerable crop losses are possible in environments conducive to the disease.

Most studies suggest that only moderate or severe sharp eyespot incidence reduces yield substantially. In the West Midlands of England reduction in yield was only $5 \%$ with $10-25 \%$ incidence of disease and 20 $25 \%$ with $80 \%$ incidence (Croxall et al. 1964). Severe infections in England and Wales reduced yields by an average of $26 \%$ (Clarkson and Cook 1983), and in East Scotland by an average of 10-12 \% (Pitt 1966). In New Zealand, yield loss was considered to be negligible when the incidence was $<10 \%$, and maximum individual yield loss was estimated at $18 \%$ (Cromey et al. 2002). Richardson et al. (1976) observed, however, that average reductions of $8 \%$ in tiller yield caused a $75 \%$ reduction in grain number and $25 \%$ reduction in grain weight. Yield losses of more than $5 \%$ are generally likely to occur in up to $20 \%$ of crops.

In Poland, in 2006-2009, in three out of four sampled sites the greatest number of shoots with sharp eyespot had symptoms in the slight (1) category. Incidence of severe disease (category 3 ) was on average 3-10 times less than incidence of slight disease. An increase in average number of shoots with slight (category 1) disease was associated with decreased grain yield only at three sites. At Sobiejuchy, the high proportion of shoots in disease categories 1-3 was associated with relatively high grain yield, suggesting that conditions here were more suitable both for disease development and crop growth.

The disease appeared on stems soon after stem extension (GS 31 onwards), in May, and developed in the summer. The disease development differed from that in the United Kingdom where its decline in summer was observed by Nicholson et al. (2002). The summer development of disease in Poland was not masked by visible senescence symptoms (if compared with the healthy plants).

Even where slight disease predominated, most grain yield variates were affected, often significantly. The largest effect was in decreasing ear dry weight, a consequence of decreased number of grains per ear.
At Minikowo, Mochełek and Sobiejuchy, 10-25\% of the yield loss in severely infected shoots resulted from decreased grain number (and consequently grain dry weight per ear) and an additional 10-26\% from reduced grain weight. This may be a consequence of the timing of disease development; infection in stems that became severely diseased would be expected to have reached a critical level earlier than in those that became moderately diseased, affecting plant development between ear emergence and flowering and to a greater extent during grain filling. The lower grain number in severely infected shoots may also result from the positioning of these shoots. They are often the youngest and smallest tillers, with small grain numbers even if healthy, because of their shorter growth period and apical dominance by the older tillers.

Although an effect of sharp eyespot on decreasing grain yield is evident, especially within individual sites, grain yield generally seemed to be determined by the amount of mineral fertilization applied. The lowest average grain yield at Mochełek (3.95 tha $^{-1}$ ) was associated with the lowest amounts of nitrogen $\left(80 \mathrm{kgha}^{-1}\right)$ and phosphorus fertilization (17 $\mathrm{kgha}^{-1}$ every year), and the highest average grain yield at Sobiejuchy $\left(8.08\right.$ tha $\left.^{-1}\right)$ with additional potassium. The latter observation supports findings of Snyder and Mascagni (1998) and Sweeney et al. (2000), who recorded increased yield in winter wheat in response to increased potassium fertilization.

It was shown that there is much variation in incidence of sharp eyespot resulting from location and year. The relatively severe disease in 2007 was associated with the relatively warm and wet autumn and winter followed by warmer and wet spring and colder and wet summer. Warmer winters and moist springs, which favour infection and colonization by $R$. cerealis, usually increase incidence and severity of disease (Clarkson and Cook 1983; Wiese 1987; Polley and Thomas 1991; Colbach et al. 1997; Cromey et al. 2002). Regional differences in incidence of sharp eyespot, which occurs most often in cooler regions, were also reported from the United Kingdom (Polley and Thomas 1991) and Canada (Hall and Sutton 1998).

Variation could also result from crop sequence, differences in mineral fertilization and type of fungicide applied. Sobiejuchy and Mochełek, with 
the greatest incidence of shoots in disease categories $1-3$, were the only sites where closely related cereals (triticale, spring and winter wheat) were used as preceding or pre-preceding crops. Sharp eyespot usually occurs more often in continuously cropped cereals, including particularly wheat (Colbach et al. 1997; Żółtańska 2005). White mustard used at Mochełek as the pre-preceding crop seemed not to contribute to disease suppression, although volatiles released from breakdown of thioglycosides have shown activity against soil-borne pathogens (Larkin et al. 2011). Low nitrogen rates at Mochełek did not decrease disease incidence as reported by Colbach et al. (1997). Different fungicides strategies were applied at different sites. Alternative application of flusilazole + carbendazim, spiroxamine + tebuconazole + triadimenol, kresoxim-methyl + epoxiconazole, fenpropimorph, azoxystrobin, prothioconazole + fluoxastrobin at Chrzastowo seemed to decrease the incidence of disease (only $49 \%$ of shoots with sharp eyespot). Azoxystrobin, reported to be active against sharp eyespot (Bateman et al. 2000), was used at three locations in Chrzastowo in 2008, Minikowo in 2006 and 2007 and Sobiejuchy in 2006 and 2007. Its application was usually associated with significant reduction of disease. Cyproconazole has some growth-regulating activity that can result in plant growth retardation (Köller 1987). This fungicide did not however affect the growth of plants at Mochełek. The dry weight of plants from Mochełek was similar to those from other sites. Variation in disease was not expected to have resulted from soil type, which was similar in all sites, being dry, light, non-compacted sandy or silty loam rather poor in organic matter. Such soil generally favours survival and colonization by $R$. cerealis (Herman 1992; Cromey et al. 2002). An effect of increasing severity category on lower plant dry weight may suggest an involvement of soil moisture not only in disease incidence but also in plant development.

Average maximum yield loss in sampled sites was estimated at $8-10 \%$ in a crop where $50 \%$ of stems were infected, $25 \%$ of them in severity categories 2 and 3. This yield loss is 2.5 times smaller than that predicted from a disease index calculated from the average proportion of tillers with severity categories 2 and 3. Such a disease index can be easily calculated. It is, however, more useful for estimating overall losses than losses in specific crops which may vary between locations and years.
Sharp eyespot tended to improve some measures of grain quality. Compared with healthy shoots, grain from diseased shoots often produced flour with more protein and wet gluten content, less alpha amylase activity, and slower sedimentation. Increased protein and gluten content are an expected consequence of decreased grain size because the proportion of endosperm carbohydrate is decreased. Protein and gluten have long been considered the most important functional constituents of wheat grain, with profound modifying effects on many functional properties of flour. Low alpha amylase activity (indicated by relatively high Hagberg falling number) is required in most baking flours as the enzyme converts starch to sugar, preventing proper dough characteristics. Slower sedimentation, shown in the tests, indicates both higher gluten content and better gluten quality.

The presence of sharp eyespot increased the incidence of $F$. poae, K. oryzae, M. bolleyi and $T$. viride on wheat grain. The importance of $F$. poae is increasingly recognized. It is one of the causal agents of fusarium head blight of wheat and may contribute to loss of grain yield and reduced germination. It has been associated with human and animal toxicoses as its strains produce a large number of mycotoxins, including trichothecenes of types $\mathrm{A}$ and $\mathrm{B}$, beauvericin and enniatins (Kulik and Jestoi 2009; Stenglein 2009). Fusarium spp. can digest proteins and starch, and infected kernels can generate technical problems in production of bread (Betchel et al. 1985). Khuskia oryzae can affect grain quality, and decrease its viability and germination (Wiewióra et al. 2009). Microdochium bolleyi can contribute to winter wheat crown rot but with no significant effect on grain yield (Kane et al. 1987). Trichoderma viride produces many secondary metabolites active in its antimicrobial activity (Sivasithamparam and Ghisalberti 1998), which may however be toxic to humans (Cole and Cox 1981; de Hoog et al. 2000).

We have shown that sharp eyespot can affect yield in conventionally grown wheat in Poland. There was generally no effective fungicidal control (Colbach et al. 1997 ) or evidence of cultivar resistance against $R$. cerealis (Wiese 1987). Recently, however, Vibrance, a proprietary seed treatment fungicide based on the new active ingredient sedaxane was launched (Crummett 2011). If chemical control is restricted, as in organic farming, recognition of factors involved in development of disease in the moderate central European climate is necessary. Results of studies on effects of different crop 
management procedures on incidence of disease may help in developing optimum practices for non-chemical disease control and maximum wheat yields.

Open Access This article is distributed under the terms of the Creative Commons Attribution License which permits any use, distribution, and reproduction in any medium, provided the original author(s) and the source are credited.

\section{References}

Anonymous. (2006). USDA National Nutrient Database for Standard Reference. http://www.nal.usda.gov/fnic/foodcomp/ search/.

Anonymous. (2010). World Wheat, Corn and Rice. Oklahoma State University, FAOSTAT. http://nue.okstate.edu/ crop-information/world-wheat-production.htm.

Bateman, G. L., Edwards, S. G., Marshall, J., Morgan, L. W., Nicholson, P., Nuttall, M., Parry, D. W., Scrancher, M., \& Turner, A. S. (2000). Effects of cultivar and fungicides on stem-base pathogens, determined by quantitative PCR, and on diseases and yield of wheat. Annals of Applied Biology, 137, 213-221.

Betchel, D. B., Kaleikan, L. A., Gaines, R. L., \& Seitz, L. M. (1985). The effects of Fusarium graminearum infection on wheat kernels. Cereal Chemistry, 62, 191-197.

Carling, D. E., \& Sumner, D. R. (1992). Rhizoctonia. In L. L. Singleton, J. D. Mihail, \& C. M. Rush (Eds.), Methods for research on soilborne phytopathogenic fungi. St Paul: American Phytopathological Society Press.

Chakraborty, S., Tiedemann, A. V., \& Tent, P. S. (2000). Climate change: potential impact on plant diseases. Environmental Pollution, 108, 317-326.

Chen, H. G., Cao, Q. G., Xiong, G. L., Li, W., Zhang, A. X., Yu, H. S., \& Wang, J. S. (2010). Composition of wheat rhizosphere antagonistic bacteria and wheat sharp eyespot as affected by rice straw mulching. Pedosphere, 20, 505-514.

Clarkson, J. D. S., \& Cook, R. J. (1983). Effects of sharp eyespot on yield loss in winter wheat. Plant Pathology, $32,421-428$.

Colbach, H., Lucas, P., Cavelier, N., \& Cavelier, A. (1997). Influence of cropping system on sharp eyespot in winter wheat. Crop Protection, 16, 415-422.

Cole, R. J., \& Cox, R. H. (1981). Handbook of toxic metabolites (pp. 152-263). New York: Academic.

Cromey, M. G., Butler, R. C., Boddington, H. J., \& Moorhead, A. R. (2002). Effects of sharp eyespot on yield of wheat (Triticum aestivum) in New Zealand. New Zealand Journal of Crop and Horticultural Science, 30, 9-17.

Cromey, M. G., Butler, R. C., Munro, C. A., \& Shorter, S. C. (2005). Susceptibility of New Zealand wheat cultivars to sharp eyespot. New Zealand Plant Protection, 58, 268272.

Croxall, H. E., Dale, W. T., \& Knight, B. C. (1964). The incidence of soil-borne diseases of cereals in the West
Midlands 1959-63. Proceedings of the British Insecticide and Fungicide Conference, 1963, 223-231.

Crummett, D. (2011). New Vibrance fungicide stops rhizoctonia. Crop Production. www.FarmProgress.com.

Daamen, R. A., \& Stol, W. (1990). Surveys of cereal diseases and pests in the Netherlands2. Stem-base diseases of winter wheat. Netherland Journal of Plant Pathology, 96, 251260.

de Hoog, G. S., Guarro, J., Gené, J. \& Figueras, M. J. (2000). Atlas of Clinical Fungi (2nd ed., p. 1126). Utrecht, The Netherlands: Centraalbureau voor Schimmelcultures.

Etheridge, J. V., Davey, L., \& Christian, D. G. (2001). First report of Rhizoctonia cerealis causing sharp eyespot in Panicum virgatum in the UK. Plant Pathology, 50, 807.

Hall, R., \& Sutton, J. C. (1998). Relation of weather, crop, and soil variables to the prevalence, incidence, and severity of basal infections of winter wheat in Ontario. Canadian Journal of Plant Pathology, 20, 69-80.

Herman, M. (1992). The effect of soil moisture on the incidence of Rhizoctonia cerealis and microbial antagonism against it. II Antagonism of the soil against $R$. cerealis as affected by temperature and soil water content. Scientia Agriculturae Bohemoslovaca, 24, 317-325.

Huynh, H., \& Feldt, L. S. (1970). Conditions under which mean square ratios in repeated measurements designs have exact F-distributions. Journal of the American Statistical Association, 65, 1582-1589.

Kane, R. T., Smiley, R. W., \& Sorrells, M. E. (1987). Relative pathogenicity of selected Fusarium species and Microdochium bolleyi on winter wheat in New York. Plant Disease, 71, 177-181.

Köller, W. (1987). Isomers of sterol synthesis inhibitors: fungicidal effects and plant growth regulator activities. Pesticide Science, 18, 129-147.

Kryuchkova, L. (2000). Stem-base diseases of wheat in Ukraine. Proceedings of the BCPC Conference-Pests \& Diseases, 2000, 113-118.

Kulik, T., \& Jestoi, M. (2009). Quantification of Fusarium poae DNA and associated mycotoxins in asymptomatically contaminated wheat. International Journal of Food Microbiology, 130, 233-237.

Kurowski, T. P., \& Adamiak, E. (2007). Occurrence of stem base diseases of four cereal species grown in long-term monocultures. Polish Journal of Natural Sciences, 22, 574-583.

Larkin, R. P., Honeycutt, C. W., \& Olanya, O. M. (2011). Management of Verticillium wilt of potato with diseasesuppressive green manures and as affected by previous cropping history. Plant Disease, 95, 568-576.

Lemańczyk, G. (2010a). Occurrence of sharp eyespot in spring cereals grown in some regions of Poland. Journal of Plant Protection Research, 50, 505-512.

Lemańczyk, G. (2010b). Occurrence of sharp eyespot (Rhizoctonia cerealis) in winter triticale grown in some provinces of Poland. Phytopathologia, 56, 27-38.

Maxwell, S. E., \& Delaney, H. D. (1990). Designing experiments and analyzing data: a model comparison perspective. Belmont: Wadsworth Publishing Company.

Mikolajska, J. \& Wachowska, U. (1996). Characterization of binucleate isolates of Rhizoctonia cerealis with respect to cereals. In M. Kowalik, \& S. kowalski (eds.), North 
Eastern Poland Symposium on New Directions in Plant Pathology, Sep 11-13 (pp. 303-306) Kraków, Poland.

Nicholson, P., \& Parry, D. W. (1996). Development and use of a PCR assay to detect Rhizoctonia cerealis, the cause of sharp eyespot in wheat. Plant Pathology, 45, 872-883.

Nicholson, P., Turner, A. S., Edwards, S. G., Bateman, G. L., Morgan, L. W., Parry, D. W., Marshall, J., \& Nuttall, M. (2002). Development of stem-base pathogens on different cultivars of winter wheat determined by quantitative PCR. European Journal of Plant Pathology, 108, 163-177.

Nyvall, R. F. (1989). Field crop diseases handbook (2nd ed.). New York: Van Nostrand Reinhold.

Pitt, D. (1964). Studies on sharp eyespot disease of cereals. I. Disease symptoms and pathogenicity of isolates of Rhizoctonia solani Kühn and the influence of soil factors and temperature on disease development. Annals of Applied Biology, 54, 77-89.

Pitt, D. (1966). Studies on sharp eyespot disease of cereals. III. Effects of the disease on the wheat host and the incidence of disease in the field. Annals of Applied Biology, 58, 299-308.

Polley, R. W., \& Thomas, M. R. (1991). Surveys of diseases of winter wheat in England and Wales, 1976-1988. Annals of Applied Biology, 119, 1-20.

Prange, A., Birzele, B., Krämer, J., Meier, A., Modrow, H., \& Köhler, P. (2005). Fusarium-inoculated wheat: deoxynivalenol contents and baking quality in relation time. Food Control, 16, 739-745.

Prew, R. D., \& McIntosh, A. H. (1975). Effects of benomyl and other fungicides on take-all, eyespot and sharp eyespot diseases of winter wheat. Plant Pathology, 24, 67-71.

Richardson, M. J., Whittle, A. M., \& Jacks, M. (1976). Yield loss relationships in cereals. Plant Pathology, 25, 21-30.

Rossi, V., Cervi, C., Chiusa, G., \& Languasco, L. (1995). Fungi associated with foot rots on winter wheat in northwest Italy. Journal of Phytopathology, 143, 115-119.

Siuda, R., Grabowski, A., Lenc, L., Ralcewicz, M., \& Spychaj-Fabisiak, E. (2010). Influence of the degree of fusariosis on technological traits of wheat grain. International Journal of Food Science and Technology, 45, 2596-2604.

Sivasithamparam, K., \& Ghisalberti, E. L. (1998). Secondary metabolism in Trichoderma and Gliocladium. In C. P. Kubicek \& G. E. Harman (Eds.), Trichoderma \& Gliocladium (pp. 139-191). London: Taylor \& Francis.

Snyder, C. S. \& Mascagni, H. J. (1998). Phosphorus and potassium increase wheat yields and help reduce disease damage. News and Views from the Southeast Region, Int. Plant
Nutrition Institute. October 1998. http://oilpalm.ipni.net/ppi web/ppinews.nsf/0/a08e675e4e0505e58525691b006678f2/ \$FILE/98166-CSS-Wheat\%20Yields.pdf. Accessed 25 October 2011.

Stenglein, S. A. (2009). Fusarium poae: a pathogen that needs more attention. Journal of Plant Pathology, 91, 25-36.

Sweeney, D. W., Granade, G. V., Eversmeyer, M. G., \& Whitney, D. A. (2000). Phosphorus, potassium, chloride, and fungicide effects on wheat yield and leaf rust severity. Journal of Plant Nutrition, 23, 1267-1281.

Tunali, B., Nicol, J. M., Hodson, D., Uçkun, Z., Büyük, O., Erdurmuş, D., et al. (2008). Root and crown rot fungi associated with spring, facultative, and winter wheat in Turkey. Plant Disease, 92, 1299-1306.

Van Der Hoeven, E. P., \& Bollen, G. J. (1980). Effect of benomyl on soil fungi associated with rye. 1. Effect on the incidence of sharp eyespot caused by Rhizoctonia cerealis. Netherlands Journal of Plant Pathology, 86, 163-180.

Wiese, M. V. (1987). Compendium of wheat diseases (2nd ed.). St Paul: APS Press.

Wiewióra, B., Mańkowski, D., \& Bulińska-Radomska, Z. (2009). Zdrowotność ziarna zbóż pochodzącego z ekologicznej produkcji nasiennej (Health of cereals seed originated from ecological seed production). Biuletyn Instytutu Hodowli i Aklimatyzacji Roślin, 251, 29-39.

Willis, W. G. (1984). Wheat diseases. Manhattan: Cooperative Extension Service, Kansas State University. Publication S23.

Wilson, A., Simpson, D., Chandler, E., Jennings, P., \& Nicholson, P. (2004). Development of PCR assays for the detection and differentiation of Fusarium sporotrichioides and Fusarium langsethiae. FEMS Microbiology Letters, 233, 69-76.

Zadoks, J. C., Chang, T. T., \& Konzak, C. F. (1974). A decimal code for the growth stages of cereals. Weed Research, 14, 415-421.

Zhalieva, L. D. (2008). Changes in a pathogenic complex of major pathogens causing root rot on grain cereals in conditions of Krasnodar. In Territory abstract. International Conference on Information Systems of Diagnostics, Monitoring and Forecasting the Major Weed Plants, Pests and Diseases of Agricultural Crops, May 12-16 (pp. 105-106) St. Petersburg-Pushkin, Russia, 120 pp.

Żółtańska, E. (2005). The effect of previous crop and weather conditions on the incidence of stem base diseases in winter wheat. Journal of Plant Protection, 45, 37-40. 